\title{
DOCUMENTING THE IMPACT OF SOCIOECONOMIC DYNAMICS ON HERITAGE SITES. THE CASE OF VISTA ALEGRE DISTRICT IN SANTIAGO DE CUBA
}

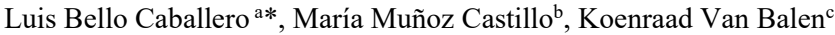 \\ ${ }^{a}$ Universidad de Oriente, Urban Planning and Architecture Dpt. Ave. Las Américas, Santiago de Cuba \& RLICC, KU Leuven, \\ Kaastelpark, Heverlee, Leuven - lbello0702@gmail.com \\ ${ }^{\mathrm{b}}$ Universidad de Oriente, Urban Planning and Architecture Dpt. Ave. Las Américas, Santiago de Cuba - marte7@uo.edu.cu \\ ${ }^{\mathrm{c}}$ KU Leuven, RLICC \& Dpt. of Civil Engineering Kaastelpark, Heverlee, Leuven - \\ koenraad.vanbalen@kuleuven.be
}

Commission II

KEY WORDS: Documentation, Socioeconomic dynamics, Mapping, GIS, Heritage sites, Cuba

\begin{abstract}
:
Recent policies adopted in Cuba are producing a significant turn into the country's socioeconomic dynamics. Past shifting circumstances have demonstrated the positive and negative implications on heritage sites. In this regard, this paper presents a first stage of a research project aimed at monitoring the impact of socioeconomic dynamics on local heritage sites. The research partial results focus on the documentation of the evolution of a case study: Vista Alegre District in the city of Santiago de Cuba. Scholars have noted that the District's urban design and historic building stock represent its most significant heritage values. Such qualities are under permanent threat due to transformations and deterioration. In order to analyse current site condition, and to understand transformations as a result of socioeconomic dynamics, a Geographic Information System (GIS) was implemented as a monitoring and documenting tool. The GIS allowed integrating data related to the evolution of the urban layout, and the heritage buildings. Data was sourced from heritage management and urban planning offices, as well as from previous studies on the site. In addition, the analysis of remote sensing imagery, and a field survey helped to update the existing records, and to include new information with the purpose of assessing the integrity of heritage values. At this stage, maps that describe the site evolution, the significant changes over time, and the alterations to character defining elements served to identify sectors of different scenic qualities. Results are essential to contribute to draft management strategies as part of decision making.
\end{abstract}

\section{INTRODUCTION}

The topicality on Cuban political panorama has been immersed since 2011 in a process of changes, mainly evidenced in shifts within current economic strategies. The announcement of the Party's Economic and Social Policy Guidelines; the encouragement of small private enterprises; the opening of the real estate market; as well as the approval of the new Law for Foreign Investment are among the most important arrangements over the last years (Peters, 2014; Rodríguez, 2013; Rodriguez, 2014). In addition, the re-establishment of the diplomatic relationship between the Cuban and United States Governments in 2014 have increased the attention of foreign investors on the island. Such events describe a situation in which is possible to foresee a gradual turn in the socioeconomic dynamics of the country.

Even though the current sequence of events predicts economic and social benefits, it will have an impact on heritage sites. These areas are the most fragile ecosystems within the broader urban environment; thus, more vulnerable to radical changes or development pressures. Past variations, in the national and international arena have demonstrated the positive and negative effects on historic buildings and urban patterns (GCI, 2009). While transformations due to new functions' improvised adaptations, alterations in facades and excessive urban soil densification represent significant threats to heritage values, the increasing deterioration caused by the lack of maintenance also leads to the loss of aesthetic qualities and heritage values (Muñoz and Bello Caballero, 2012; Gómez Ortega et al., 2013). In this regard, cultural heritage documentation is the first step to develop suitable approaches and strategies for appropriate interventions. (Letellier, 2007)
Geographic Information Systems (GIS) have been widely used as a documentation, monitoring and management tools within the cultural heritage field (Myers et al., 2016; Rinaudo et al., 2007). The capacity of such systems to interrelate data from diverse sources, formats or levels of resolution has made it a powerful resource for spatial information analysis (Campagna, 2006). GIS assist in documenting different urban features along with their role in modelling processes which have effects on heritage sites (Sharaf et al., 2008). On this view, this paper introduces the implementation of a GIS as a tool for documenting the evolution of Vista Alegre District in the city of Santiago de Cuba. The case study is an urban heritage site with recognized values, which are mainly expressed in the spatial organization, and the historic building stock.

The GIS implementation on Vista Alegre has helped to improve the visualization and understanding of the impacts resulting from political-economic changes. Furthermore, heritage values, transformations and current site condition were mapped aiming at identifying sectors of scenic values; which can be a support to address intervention actions. The future of heritage management has been reportedly stated to "become increasingly more about thoughtful change rather than solely the protection of historic buildings and ensembles'(Veldpaus et al., 2013, p. 13). In this regard, results belong to a broader research project that goes into a comprehensive understanding of the nature and extent of the District as a heritage site. The extensive study is based on the preventive conservation approach (Van Balen and Vandesande, 2013) and considers the sustainable development dimensions in order to contribute to draft management plans and support decision-making process. Further work needs to focus on specific threats to the architectural set by thoroughly examining its condition. 


\section{THE CASE STUDY}

The former Finca 'Arroyo Hondo' located towards the East peripheries of the city of Santiago de Cuba was the area chosen for the establishment of Vista Alegre District, which emerged there in 1907. The area had optimal environmental conditions, its highland positioning propitiated panoramic views over a rich and diverse natural landscape. Such characteristics were key features that were decisive for the location of the new urbanization. Eventually, the District became a highly relevant example within the local urban planning praxis during the $20^{\text {th }}$ century. Trends coming from the capital city -Havana-, as well as foreign influences, mostly from the United States, were incorporated into the notion of the urban layout in order to respond to the demands of wealthy social class. Therefore, the settlement meant a different vision if compared to the inherited colonial spatial organization. (Muñoz, 2007)

Modern ideas of the period were materialized in the proposed urban layout; which was inspired in the paradigm of garden cities (Muñoz, 2005), firstly developed in the UK, and further extended from Europe to North America. Therefore, based on that paradigm, roads and blocks were enlarged in order to leave enough free space around the buildings. Green areas like parterres on both sides of streets, front gardens preceding and emphasizing accesses and facades, as well as large backyards were part of the fundamentals considered. Additionally, a longitudinal garden along the central avenue was conceived to accentuate the character of the site. That spatial structure was a novel experience at that moment within the city planning evolution. (Fig.1)

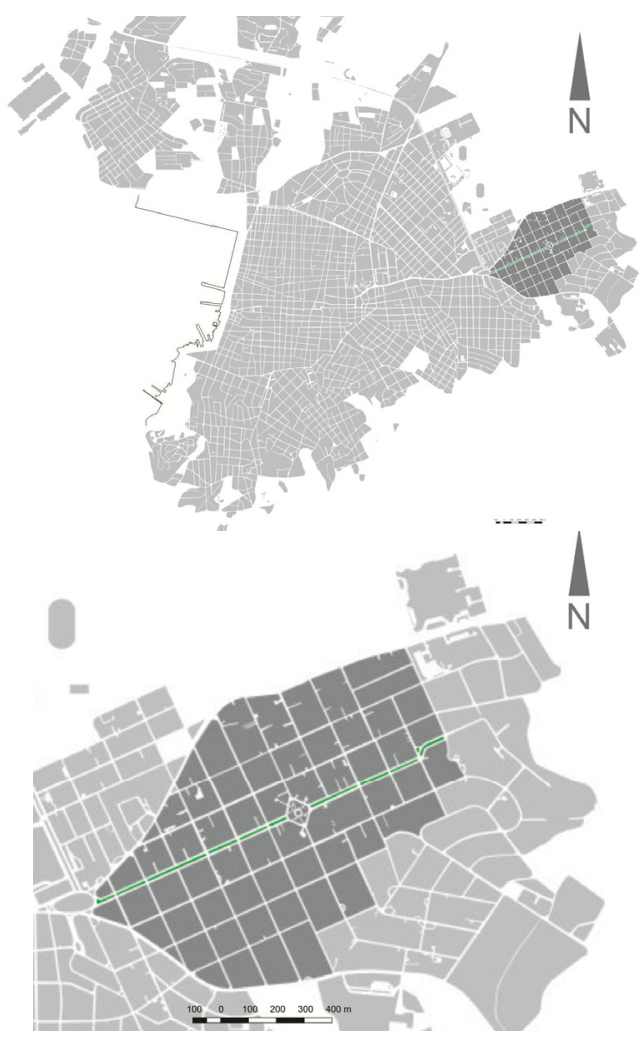

Figure 1. Location of Vista Alegre in Santiago de Cuba and detail of urban pattern
Furthermore, the typology of buildings recreates a volumetric richness without spatial constraints thanks to the urban layout flexibility. As a result, a set of fresh housings with cross ventilation, open air spaces, large openings and generous heights were adapted to topography and climate conditions. These, along with the manifold stock of clay tile roofs, are some of the District's character defining elements. Noteworthy, is the concentration of diverse stylistic influences developed in Cuba from late $19^{\text {th }}$ to mid- $20^{\text {th }}$ centuries. Exponents of neoclassicism, eclecticism, Art Deco, California missionary, Mediterranean and Rationalism influences compose a remarkable architectural collection. The articulation of diverse aesthetic manifestations propitiated the formation of the residential zone, where built environment and green areas integrate in a coherent monumental image. (Morcate and Parrinello, 2008; Muñoz, 2005) (Fig.2)
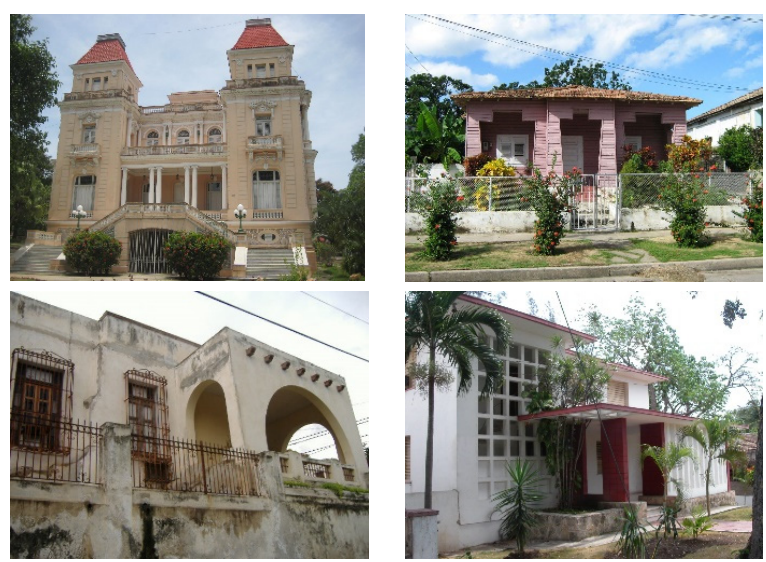

Figure 2. Examples of Vista Alegre's architectural collection. Note the integration of green areas. Source: authors' archives

Substantial changes took place during the second half of the $20^{\text {th }}$ century. One of the consequences of the radical Revolution in 1959 was the massive migration of families over the 1960 s, leaving behind their possessions in the District. Few housekeepers were left in charge of abandoned goods; but, in most cases the nascent Government appropriated them. Aiming at erasing any link to the past Cuban Republican Society, former houses were adapted to host public institutions, schools and administrative offices. Exceptionally, some of the houses were transferred to private owners with outstanding achievements in their professional careers, mainly related to armed forces or sports. This policy continues till today. Such circumstances introduced a different character to the site, ranging from a predominantly residential use to a more active public urban dynamic.

Industrial construction systems were massively introduced in Cuba during the subsequent decades -1970 s, 1980s- (De Las Cuevas Toraya, 2001). Based on these technologies, social housings, basic health services, markets and a small number of office buildings filled almost all District's available plots. Later on, the fall of the Communist Bloc produced an abrupt economic crisis that immediately rebounded on the country. Consequently, a long period of shortcomings and resources scarcities followed from 1990 onwards, leading to acute deterioration and irreversible modifications on buildings and urban fabric. For instance, properties divisions into two or three parts due to relatives' separation, incompatible additions, as well as green area reduction caused by emerging low-cost constructions and parking lots are still visible impacts. (Fig. 3) 


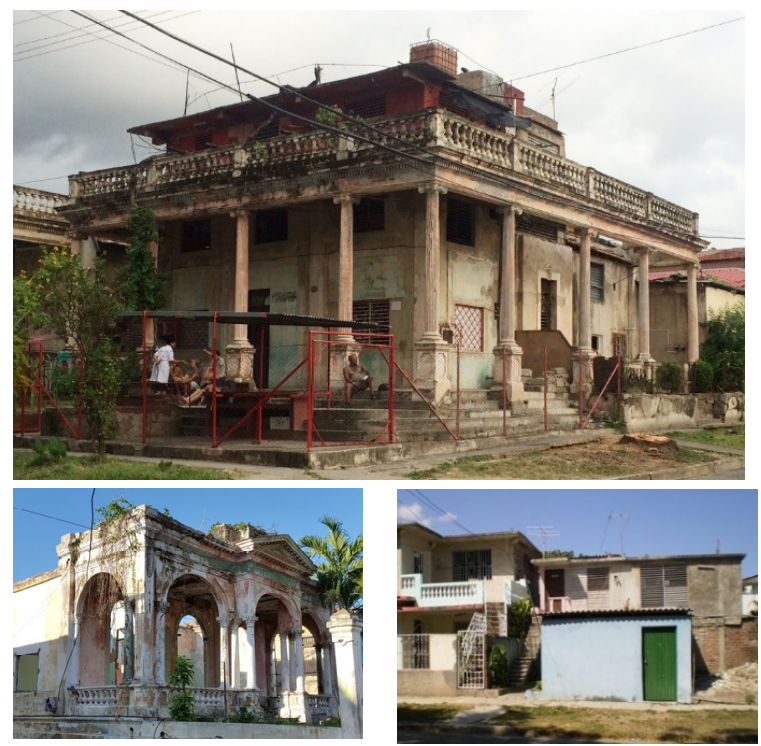

Figure 3. Transformations, decay and negative insertions in Vista Alegre. Source: authors' archives

Nowadays, increasing decay of buildings, neglect, illegal transformations, unfitted constructions and soil misuse are consequences of the lack of effective instruments for urban control. In view of that, some positive actions have been undertaken by the local government in collaboration with the City Conservation Office (OCC). Administrative offices were moved out to incorporate other functions -lodging, art galleries, museums- in order to revitalize urban dynamics. However, economic resources limit a holistic view of the problem; attention is focused only on central areas or state properties.

Within the private sector, the situation is rather complex. The opening of the real estate market in 2011 resulted in investments rising, a trend that has conditioned the displacement of locals. Families see the opportunity to reach a better economic status by selling their houses. In the best case scenario new owners recover buildings from bad conditions; while in the worst, severe alterations are caused due to the incorporation of small businesses.

Several efforts by scholars have contributed from different perspectives to recognize, valorise, disseminate and protect Vista Alegre's cultural values (Morcate and Parrinello, 2008; Muñoz and Bello Caballero, 2012; Bello Caballero et al., 2013; Soto et al., 2015). Nonetheless, the District still lacks legal heritage protection or integral management strategies. In this regard, the present study joins and assimilate previous approaches, it particularly follows authors' pilot experience in 2013. At that moment, an inspection on the site's general condition, as well as the potentialities for tourism development, and disaster risk preparedness were the topics addressed (Bello Caballero et al. 2013). This paper emphasizes on the setting of a GIS-based tool that can serve as an inventory, documentation, analysis and monitoring resource.

\section{GIS IMPLEMENTATION}

Both literature survey and the analysis of different case studies (Fusco Girard and De Toro, 2007; Sharaf et al., 2008; Seker et al., 2010; Husseini and Bali, 2015) conducted to pose two main questions as the starting point for the GIS implementation: a. What elements should be documented? b. Which are the data sources?

What elements should be documented? International seminal documents, meeting reports on the topic; as well as prior studies on the site, which aimed at examining impacts on cultural assets through historical context evolution, helped to build the theoretical and methodological framework. Accordingly; the Washington Charter (ICOMOS, 1987); the Recommendation Concerning the Safeguarding and Contemporary Role of Historic Areas (UNESCO, 1976); the Report on Historic Urban Environment, Conservation Challenges and Priorities for Action (GCI, 2009); the Historic Urban Landscape approach (UNESCO, 2011) and research reports (Muñoz, 2007; Soto, 2006; Muñoz and Bello Caballero, 2012) were -among othersessential to identify the qualities to be documented and the analysis to be conducted.

The theoretical background, which emphasizes on approaches and methods to address studies related to heritage sites, determined guidelines in order to conduct a comprehensive survey and mapping of the District cultural values. The survey encompassed the urban pattern, defined by blocks, plots and streets; the articulation between built environment and green open spaces; and the formal exterior appearance of buildings as defined by scale, size, style, construction, materials, and decoration. Likewise, it was essential to understand the District various functions acquired over time; as well as the threats that compromise the integrity and authenticity of values.

According to the aforementioned aspects, the GIS baseline layers were defined by the urban layout (blocks, plots, streets, green areas) and buildings; in which the different features, and attributes were incorporated (Table 4). The next step was to find sources for data acquisition.

Which are the data sources? An initial challenge faced was the generalized little experience existing in Cuba around heritage inventories and documentation. Despite the recognized achievements on the conservation of heritage sites, there are still gaps to be filled in the area of information management (Rodríguez Alomá et al., 2012). A singular case worth mention is the Office of the Historian City in Old Havana $(\mathrm{OHCH})$. The study, understanding, and intervention actions undertaken by the $\mathrm{OHCH}$ is supported on a GIS-based Territorial Information System (SIT, www.sit.ohc.cu). Particularly in Santiago de Cuba, GIS platforms have been implemented by GeoCuba ${ }^{1}$ and the Provincial Department for Urban Planning (DPPF); however, they focus mainly on territorial information management. In this regard, specific heritage-related data was unavailable except for the District's plans in CAD format acquired from DPPF. Therefore, the GIS tool was built from existing conventional records since no heritage geospatial data had been structured in compatible GIS formats (i.e. vector/raster layers, datasets).

Preceding reports of studies on the site worked as the basis to both, retrieve data and locate information sources. The City Historical Archives, the OCC, the DPPF, and the Department of Architecture and Urban Planning at Universidad de Oriente (UO) are the main institutions that store and produce records

${ }^{1}$ This institution is attached to the Ministry of Armed Forces (FAR). Their scope is to produce all maps of Cuba. No data were acquired from them due to internal policies. 
about the site. However, data meet the diverse needs of each organization since they work independently. Therefore, an added contribution of the proposed GIS tool is the integration of records sourced from different backgrounds.

Two field surveys in 2013 and 2015 were conducted in order to verify and eventually update existing information (Table 4); it also allowed complementing the registries with additional data. On site work activities were possible thanks to the participation of a group of third year students from the Architecture program at UO. They contributed as well in the process of data input, always under supervision of the team of researchers. appearance were also stored by means of imagery archives and photographic survey.

At this point, several analyses permitted to document the heritage qualities and the transformations produced by the socioeconomic dynamics in two periods: i. 1907-1959 (emergence and consolidation of the District) and; ii. 1960present (site's development shift and adaptation to new conditions). Upon that basis, it was possible to depict the District by sectors of different scenic qualities considering the transformations on facades, buildings condition, and alterations to green areas. All analyses concentrate on assets from the first

\begin{tabular}{|c|c|c|c|c|c|}
\hline & \multicolumn{5}{|c|}{ GIS basic structure } \\
\hline Data source & \multirow{2}{*}{\multicolumn{5}{|c|}{ Attributes }} \\
\hline & & & & & \\
\hline$D P P F$ & $\begin{array}{l}\text { CAD file base } \\
\text { map }^{1} \\
\text { Number (cadaster) }\end{array}$ & $\begin{array}{l}\text { CAD file base map } \\
\text { Identification } \\
\text { Classification }\end{array}$ & $\begin{array}{l}\text { CAD file base map }{ }^{1} \\
\text { Number (cadaster) }\end{array}$ & $\begin{array}{l}\text { CAD file base map } \\
\text { Classification }\end{array}$ & CAD file base map ${ }^{1}$ \\
\hline $\begin{array}{l}\text { Research } \\
\text { reports }\end{array}$ & $\begin{array}{l}\text { Classification by } \\
\text { area and shape }{ }^{2} \\
\text { Urban regulations }^{2}\end{array}$ & & $\begin{array}{l}\text { Classification by area } \\
\text { and shape } \\
\text { Urban regulations }^{2} \\
\text { High value sector }\end{array}$ & & $\begin{array}{l}\text { Architectural style } \\
\text { Original use }^{2} \\
\text { Housing typology } \\
\text { High value buildings } \\
\text { Divided buildings }\end{array}$ \\
\hline $\begin{array}{l}\text { OCC / City } \\
\text { Historical } \\
\text { Archive }\end{array}$ & $\begin{array}{l}\text { Historic } \\
\text { cartography }\end{array}$ & $\begin{array}{l}\text { Historic } \\
\text { cartography }^{3}\end{array}$ & Historic cartography ${ }^{3}$ & & $\begin{array}{l}\text { Historic imagery } \\
\text { Level of protection }^{2} \\
\text { Year }^{5} \\
\text { Period } \\
\text { Ownership }\end{array}$ \\
\hline Field survey & & Dimensions $^{2}$ & & $\begin{array}{l}\text { Alterations in green } \\
\text { areas }^{2}\end{array}$ & $\begin{array}{l}\text { Condition assessment }{ }^{2} \\
\text { Stories }^{2} \\
\text { Current use }^{2} \\
\text { Building typology }^{2} \\
\text { Roof typology } \\
\text { Facade typology } \\
\text { Integrity of façade }^{2} \\
\text { New constructions } \\
\text { Photography of façade }\end{array}$ \\
\hline $\begin{array}{l}\text { Remote } \\
\text { sensing } \\
\text { imagery }\end{array}$ & & & $\begin{array}{l}\text { Reduction of green } \\
\text { areas: gardens, } \\
\text { backyards }^{3-1}\end{array}$ & $\begin{array}{l}\text { Reduction of green } \\
\text { areas: parks, parterres, } \\
\text { central av. garden }\end{array}$ & $\begin{array}{l}\text { Emerging } \\
\text { constructions at the } \\
\text { interior of blocks }\end{array}$ \\
\hline
\end{tabular}

Table 4. General GIS structure according to layers, attributes and data sources.

As presented in Table 4, the base plan was a CAD file, ultimately converted into vector layer and georeferenced according to NAD 27/Cuba Sur coordinate system. To this end, QuantumGIS, a free and open source software (http://www.qgis.org) was used to conduct most of the operations. For instance, the 'OpenLayers' plugin permitted to add complementary web-based layers such as 'Open Street Map' and 'Google Satellite' in order to accurately check coordinates and features. Particularly, the 'Google Satellite' web-based layer helped to visualize transformations to urban layout; i.e. emerging construction at the interior of blocks, and reduction of private and public green areas.

The database is mostly composed by alphanumeric data; furthermore, date fields, as well as raster layers were also integrated aiming at examining impacts and the evolution from former to present circumstances. Records on heritage buildings already lost, current external condition, and facades' formal period -henceforth heritage buildings- since they define the spirit of the place, and express the District's aesthetic qualities; as it has been confirmed in previous studies (Soto, 2006; Muñoz, 2007; Morcate and Parrinello, 2008). Moreover, this architectural set represents most of the building stock, $70 \%$ out of total.

\section{DOCUMENTATION OF SITE'S EVOLUTION AND SOCIOECONOMIC IMPACTS}

The information retrieved from historical archives and the studies on Cuban architecture permitted to document plots occupancy over the first period's five decades. Accordingly, a map of urban pattern consolidation and architectural styles shows how different influences were gradually introduced. Three main moments -1920-30s; 1940s; and 1950s- determined an intensive growth of Vista Alegre. Influences of Eclecticism, Californian, and Rationalism, had respectively a boom during 
those segments of time; as a result, they are the most represented aesthetic influences. The first one concentrated around central areas, while the second and third are more visible to the periphery. However, other influences coexisted and completed the richness of heritage values. (Fig. 5)

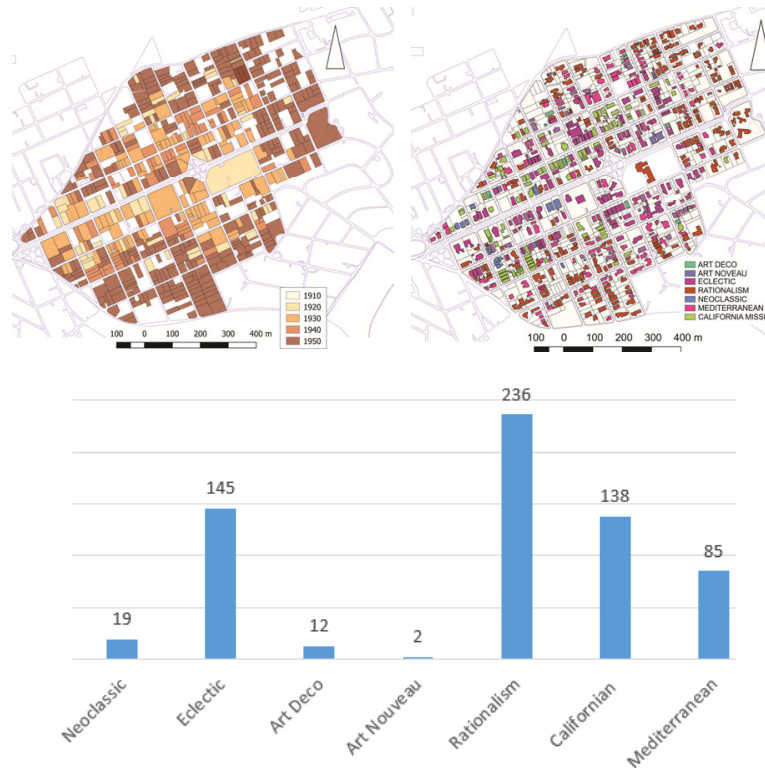

Figure 5. Consolidation of the District and diversity of architectural influences during the early years.

Almost every property in the site was of private tenancy, and housing was the predominant use. Exceptions like the 'Sagrada Familia' Catholic Church, and the former Vista Alegre Park were places that propitiated social gathering. The latter included a number of functions for recreation, among them gastronomic services, a theatre, and installations for leisure activities. As a whole, the District had an enclosure character, with privileges only for resident families. That was the purpose of the urbanization but it also accentuated existing social segregation.

This situation changed after 1959, when the Revolutionary State took over abandoned properties. Hence, new functions appeared, producing an integration of the isolated urban island within the city's broader dynamics. Public social services, educational centres, cultural institutions and community health units were among the uses incorporated into heritage buildings. In this regard, the data acquired from previous research reports incorporated into the GIS database helped to examine the changes in ownership, and consequently in the function of heritage buildings. (Fig. 6)

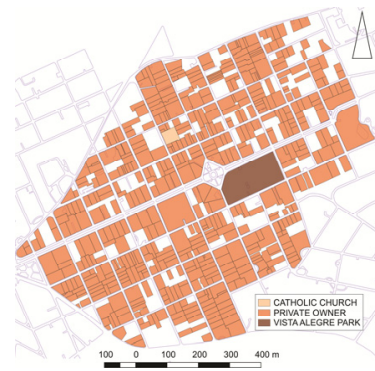

Ownership before 1959

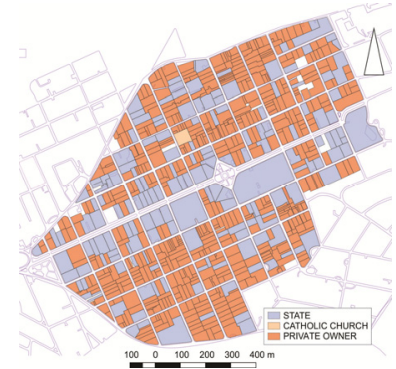

Current ownership

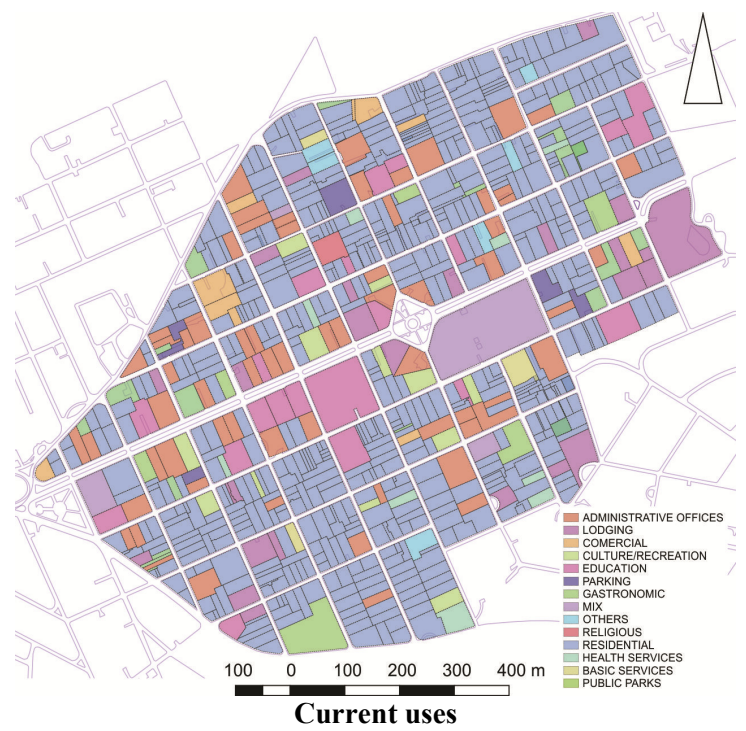

Figure 6. Site's development shift, adaptation to the new political context

The interior spatial distribution of buildings was adapted in order to host offices, archives, classrooms, student residences or meeting rooms. This, logically conducted to floor plan transformations to meet the needs of new activities. Negative impacts started when such modifications occasioned mutilations to facades. Alterations to volumetric proportions or damages to decorative features are consequences of windows relocation, change or addition, along with the closuring of open spaces, and incoherent arbitrary insertions. The extended economic crisis during the transition from $20^{\text {th }}$ to $21^{\text {st }}$ century also rebounded on the District. A generalized deterioration is visible in roof structures, floor mosaics, columns, capitals, balusters and mouldings. That period equally affected the private sector, leading to the same issues seen in public properties.

In this regard, current transformations and buildings state of conservation were assessed. The first aspect encompasses two variables: facades and floor plans. Accordingly, three categories of transformations were considered: i. little, defined by the presence of reversible alterations; ii. medium, defined by additions affecting the aesthetic appearance; and iii. high, defined by irreversible modifications that resulted in the loss of character-defining elements. It is necessary to note that in the case of floor plans, a thorough assessment was not possible due to the limited access to the interior of buildings, particularly in State owned properties. In this case, an external visual examination helped to deduct the level of transformation; this was possible mainly in the housing stock since internal divisions are clearly evidenced in facades.

The second aspect -state of conservation- encompasses three scales going from good to bad. Buildings with optimal constructive condition were evaluated as good, while those presenting severe damages in at least one element (external walls, columns, roofs) were classified as bad. The category in between -fair- includes properties with a certain degree of damage that does not compromise its structural integrity. Queries in QuantumGIS allowed to statistically visualize and compare the current condition of heritage buildings. (Fig. 7) 


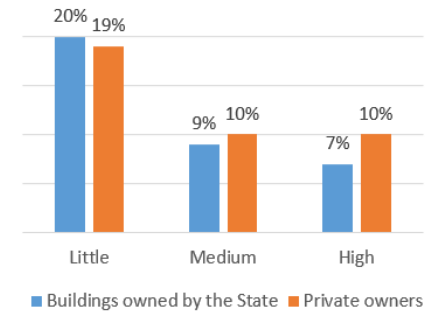

Tranformations

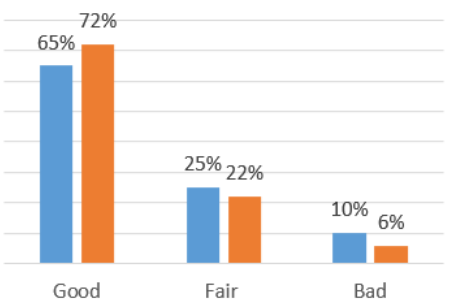

n Buildings owned by the State 1 Private owners

\section{State of conservation}

Figure 7. Comparison between state and private owners considering transformations and state of conservation

The analysis in Figure 7 reveals the similar condition regarding impacts on private and state owned heritage buildings when proportionally compared to the total of each sector properties (514, private; and 168, state). Little difference is noticed in the state of conservation; however, the situation is always rather unfavourable to the housing stock since it represents a larger number of assets, $75 \%$.

Moreover, transformations to urban pattern are currently being examined considering two aspects: the relation 'street-parterregarden-facade', and the condition of open green areas (gardens and backyards). Low, medium and high level of alterations are being recorded by means of field survey and remote sensing imagery. The latest, accessible from Google Satellite through the 'OpenLayers' plugin in QuantumGIS helped to detect emerging constructions at the interior of blocks (Fig. 8). Current analyses are being conducted in order to thoroughly determine the reduction of green areas. Compared to buildings, the preliminary results are more positive, most of open green spaces have not suffered severe changes yet.
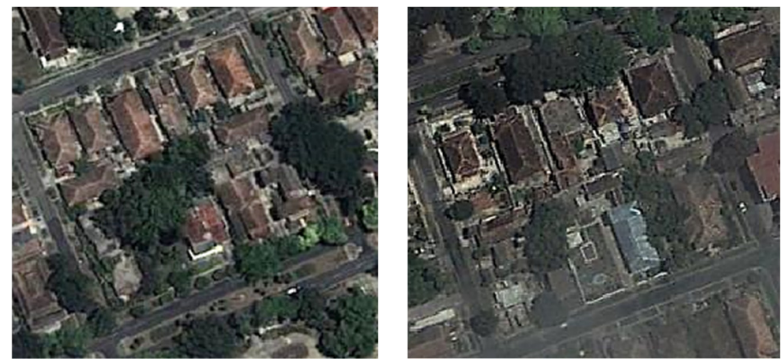

Figure 8. Comparison between two blocks. Note in the right image the reduction of green areas at the interior of the block.

Source: Google Satellite-OpenLayers plugin in QGIS

Mapping the deterioration and transformations on buildings and plots permitted to visualize areas in the District where alterations are more and less frequent. This helped to trace a zoning regarding sectors of scenic quality classified by low, medium, and high (Muñoz, 2007). By overlapping the different analyses, it was possible to depict where site's character- defining elements present severe and almost irreversible alterations (low scenic quality). Likewise, those areas where small interventions can help to reinstate heritage values (medium scenic quality). As well as the segments where even if little transformation is visible, almost all aesthetic qualities, along with original urban pattern conserve the integrity (high scenic quality). (Fig. 9)

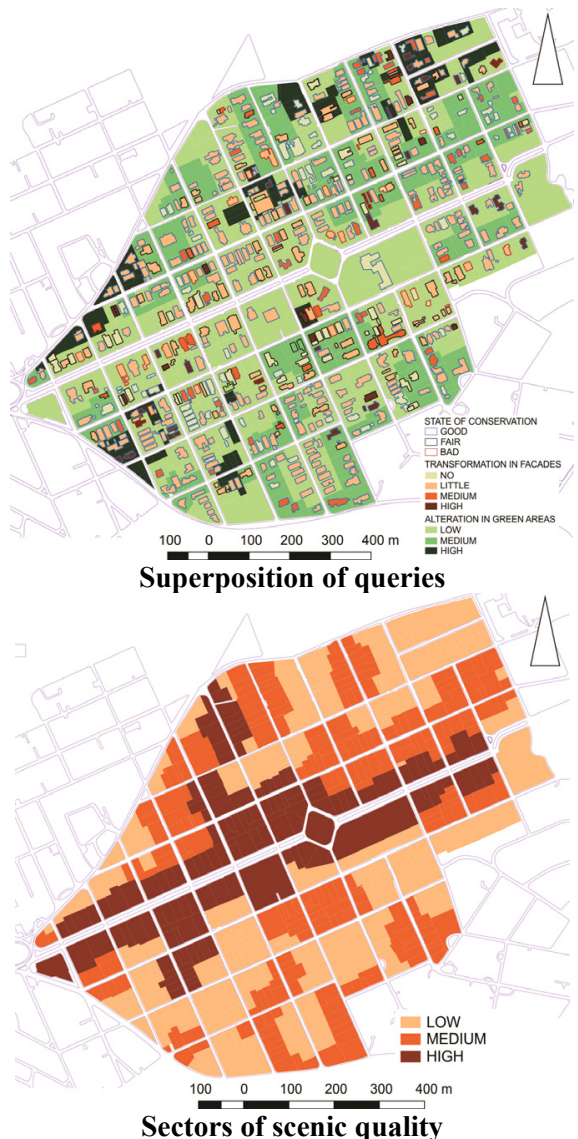

Figure 9. Analyses overlapped and resulting sectorization

District's sectorization shown in Figure 9 can assist future studies and intervention actions to address potentially vulnerable heritage values. The documentation of the impact of past circumstances can also assist to foresee possible impacts of current shifting economic policies. Few examples of this shift are already perceived in the field survey performed in 2015, even though they cannot yet be evidenced on the map. Both positive and negative practices are happening. Furthermore, processes like gentrification are possibly to be at an incipient stage since families tend to sell their properties as an alternative to economic scarcities. In this sense, a dichotomy is arising: on the one hand, a number of locals cannot afford a major repair or a gradual maintenance; on the other, emerging private businesses -with the participation of foreign investors- recover deteriorated buildings on expense of residents' displacement. Those reasons arise a question that can be posed: is this the start of a new period of transformations taking place in Vista Alegre?

\section{CONCLUSIONS}

Understanding the evolution and impacts on heritage sites brought by socioeconomic conditions at certain periods is critical to draft management strategies for the preservation of 
values in future shifting circumstances. The presented approach revealed historical phenomena by means of GIS analytical resources such as maps, imagery and statistical data. The study of overlapping trends helped to identify the areas where alterations had a negative impact on Vista Alegre District's values integrity and those areas where most character-defining elements still remain.

Accordingly, the documentation of the development, transformations, and site's current condition permitted to examine the level of degradation of the building stock and urban pattern. On the one hand, the site evolved from a predominantly (exclusive) residential private area to a more active and integrated District within the city public dynamics. On the other hand, the 'forced' evolution together with the severe economic crisis resulted in the loss, deterioration, and transformation of a significant number of heritage buildings. These phenomena are evident in both, State owned and private owned buildings. Proportionally compared, the socioeconomic changes seems to impact equally on both sectors; however, since the private sector predominates in number of assets, it has been more affected.

In addition, this paper reaffirms the advantages of GIS as a tool for documenting, monitoring and managing data within the cultural heritage field. Alphanumeric and photographic records incorporated into vector and raster layers helped to build registries for a comprehensive description of Vista Alegre as a heritage site. The capability to integrate, relate and examine information allowed through multicriteria analysis to contribute to the studies of the District's cultural legacy to Cuban urban and architectural historic practice.

\section{FURTHER WORK}

As part of the ongoing study, further actions will be conducted in order to fill the existing documentation gaps due to the lack of a thorough inspection of all District's heritage assets, which determines the absence of a comprehensive mapping of cultural resources. In this regard, an atlas is currently under preparation that will encompass a detailed survey of architectural and urban qualities.

\section{ACKNOWLEDGEMENTS}

The presented results are part of a broader research within the Project 4 'Enhancing cultural heritage preservation' ascribed to the Program 'The Universidad de Oriente supports the sustainable development in Eastern Cuba'; funded by the institutional collaboration established between the Council of Flemish Universities in Belgium (VLIR) and the Universidad de Oriente in Santiago de Cuba. Likewise, the study was supported by the VLIR North-South-South project 'Latin American Axe on Preventive Conservation of Built Cultural Heritage' that involves researchers from Universidad de Cuenca in Ecuador, Universidad de Oriente, and the KU Leuven in Belgium. Additionally, this work has also been sustained by the Carleton Immersive Media Studio at Carleton University in Canada through the funding of the Emerging Leaders for the Americas Program. It is also necessary to acknowledge the inputs of the students of the $3^{\text {rd }}$ year of the Architecture and Urban Planning Program at UO during the academic years 2013-14 and 201516.

\section{REFERENCES}

Bello Caballero, L., Soto Suárez, M., Muñoz Castillo, M.T., Pérez Vilorio, L., 2013. Los SIG como herramienta para optimizar la gestión del reparto Vista Alegre en Santiago de Cuba. Arquit. Urban. 34, 19-31.

Campagna, M. (Ed.), 2006. GIS for sustainable development. CRC Press, Boca Raton, USA.

De Las Cuevas Toraya, J., 2001. 500 Años de Construcciones en Cuba. Chavín, Servicios Gráficos y Editoriales, S.L., La Habana, Cuba.

Fusco Girard, L., De Toro, P., 2007. Integrated spatial assessment: a multicriteria approach to sustainable development of cultural and environmental heritage in San Marco dei Cavoti, Italy. CEJOR 15, 281-299. doi:10.1007/s10100-007-0031-1

GCI, 2009. Historic Urban Environment. Conservation Challenges and Priorities for Action (Meeting Report). Getty Conservation Institute, Los Angeles, CA, USA.

Gómez Ortega, G., Morcate Labrada, F., Soto Suárez, M., 2013. Consideraciones generales de la contaminación sónica en sitios patrimoniales, in: Contaminación Sónica de Sitios Patrimoniales. Dirección de Fomento Editorial, Benemérita Universidad Autónoma de Puebla, México, pp. 12-13.

Husseini, B., Bali, Z., 2015. Documentation, using GIS techniques in conservation of a World Heritage Site, a case study of "The Old City of Jerusalem." ISPRS Int. Arch. Photogramm. Remote Sens. Spat. Inf. Sci. XL-5/W7, 229-234. doi:10.5194/isprsarchives-XL-5W7-229-2015

ICOMOS, 1987. Charter for the Conservation of Historic Towns and Urban Areas.

Letellier, R., 2007. Recording, Documentation, and Information Management for the Conservation of Heritage Places. Guiding Principles. The Getty Conservation Institute, Los Angeles, USA.

Morcate, F., Parrinello, S. (Eds.), 2008. El Reparto Vista Alegre en Santiago de Cuba. Edifir, Edizione Firenze, Firenze, Italia.

Muñoz, M., 2005. El reparto Vista Alegre un paradigma del urbanismo en Santiago de Cuba. Arquit. Urban. 1.

Muñoz, M.T., 2007. Los valores urbanísticos del Reparto Vista Alegre en Santiago de Cuba (Doctoral Research). Facultad de Construcciones, Universidad de Oriente y Facultad de Arquitectura, Instituto Superior Politécnico José Antonio Echeverría', Santiago de Cuba.

Muñoz, M.T., Bello Caballero, L.E., 2012. Nuevos Preceptos Para Regulaciones Urbanas Del Reparto Vista Alegre En Santiago De Cuba. Urbano.

Myers, D., Dalgity, A., Avramides, I., 2016. The Arches heritage inventory and management system: a platform for the heritage field. J. Cult. Herit. Manag. Sustain. Dev. 6, 213-224. doi:10.1108/JCHMSD-022016-0010

Peters, P., 2014. Cuba's New Real Estate Market (Latin America Initiative Working Paper). The Brookings Institution.

Rinaudo, F., Agosto, E., Ardissone, P., 2007. GIS and WEBGIS, commercial and Open Source platforms: general rules for cultural heritage documentation. Int. Arch. Photogramm. Remote Sens. Spat. Inf. Sci. 36, 625630 . 
Rodríguez, J.A., 2013. Aumenta el trabajo por cuenta propia Cuba - Juventud Rebelde - Diario de la juventud cubana.

Rodriguez, L., 2014. Se inscriben más trabajadores por cuenta propia. Granma.

Rodríguez Alomá, P., Fornet Gil, P., León Candelario, I., Zamora Rielo, R. (Eds.), 2012. Luces y Simientes. Territorio y Gestión en Cinco Centros Históricos Cubanos. Ediciones Boloña, La Habana, Cuba.

Seker, D.Z., Alkan, M., Kutoglu, H., Akcin, H., Kahya, Y., 2010. Development of a GIS Based Information and Management System for Cultural Heritage Site; Case Study of Safranbolu, in: Facing the Challenges Building the Capacity. Presented at the FIG Congress, Sydney, Australia.

Sharaf, A., Haddad, N., Fakhoury, L., Baqaen, S., 2008. A GIS analysis of the impact of modern practices and polices on the urban heritage of Irbid, Jordan. Cities 81-92.

Soto, M., 2006. La vivienda del movimiento moderno en Santiago de Cuba (Doctoral Research). Facultad de Construcciones, Universidad de Oriente y Facultad de Arquitectura, Instituto Superior Politécnico José Antonio Echeverría", Santiago de Cuba.

Soto, M., Muñoz, M.T., Carvajal, L., Muñoz, C.M., 2015. Félix Antonio Muñoz Cusiné y su trascendencia dentro de la arquitectura moderna de Santiago de Cuba. Arquit. Urban. 36, 35-52.

UNESCO, 2011. UNESCO Recommendation on the Historic Urban Landscape [WWW Document]. UNESCO World Herit. Cent. URL http://whc.unesco.org/en/activities/638/ (accessed 11.16.16).

UNESCO, 1976. Recommendation concerning the safeguarding and contemporary role of historic areas (Records of the 19th Session No. Volume I), Records of the General Conference. UNESCO, Nairobi.

Van Balen, K., Vandesande, A. (Eds.), 2013. Reflections on Preventive Conservation, Maintenance and Monitoring of Monuments and Sites, PRECOMOS UNESCO Chair. ACCO, Leuven, Belgium.

Veldpaus, L., Pereira Roders, A.R., Colenbrander, B.J.F., 2013. Urban Heritage: Putting the Past into the Future. Hist. Environ. Policy Pract. 4, 3-18. doi:10.1179/1756750513Z.00000000022 